\title{
Screening of Some Fungi Associated with Maize Cob Degradation for Cellulase Activity
}

\section{Bamigboye 0. 0.}

\author{
Department of Biology, Emmanuel Alayande College of Education, Oyo.
}

ARTICLE INFO

Article No.: 011613389

DOI: 10.15580/GJAS.2013.6.011613389

Submitted: 16/01/2013

Accepted: 22/06/2013

Published: 29/06/2013

${ }^{*}$ Corresponding Author

Bamigboye O. 0 .

E-mail: bamigboyetaitoy@

yahoo.com

Keywords:

Cellulase, Fungi, Reducing Sugar,

Maize-cob, Biodegradation
Fungi involved in the biodegradation of maize- cob were isolated and screened for cellulase activity using glucose and carboxylmethyl cellulose as carbon sources. The effect of the carbon sources on cellulase production was determined. Eleven fungi species were isolated which include Rhizopus oryzae, Aspergillus flavus, Mucor racemosus, Aspergillus niger, Penicillium atrovenetum, Penicillium expansum, Botryotrichum piluliferum, Penicillium chrysogenum and Penicillium restictum. Effect of carbon source on cellulase production was also reported. The highest reducing sugar production for all fungi isolate was obtained on day 14 when carboxymethyl cellulose (CMC) was used as the carbon source; while the highest reducing sugar production was obtained on day 7 when glucose was used as the carbon source. Aspergillus niger had the highest production of reducing sugar $(1.68 \mathrm{mg} / \mathrm{ml}$ and $0.82 / \mathrm{m})$ in $C M C$ and glucose respectively while the lowest production was recorded for Mucor racemosus $(0.69 \mathrm{mg} /, \mathrm{ml}$ and $0.01 \mathrm{mg} / \mathrm{ml})$. All Aspergillus species and Penicilluim species isolated had very high reducing sugar production in CMC: Aspergillus flavus $1.24 \mathrm{mg} / \mathrm{ml} ; A$ oryzae $1.08 \mathrm{mg} / \mathrm{ml}, P$ expansum $1.60 \mathrm{mg} / \mathrm{ml}, P$ atrovenetum $1.43 \mathrm{mg} / \mathrm{ml}$ except Penicillium chrysonenum and Penicillium restrictum with $0.78 \mathrm{mg} / \mathrm{ml}$ and $0.81 \mathrm{mg} / \mathrm{ml}$, respectively.

Aspergillus and Penicillum species are good cellulase producers especially those that are associated with degrading maize cob. These organisms are considered suitable to increase the nutrient of maize- cob, an agro industrial waste and consequently make them useful for animal feed production. 


\section{INTRODUCTION}

Agricultural wastes which include maize- cob are among the causes of environmental pollution. Their conversion to useful products may ameliorate the problems they cause. Proper biotechnological utilization of these wastes in the environment will eliminate pollution and convert them into useful byproducts (Milala, 2005).

Cellulose and Hemicellulose which form about 85 percent of maize cob (Tuah and Oskor, 1990) is commonly degraded by an enzyme called cellulase. This enzyme is produced by several microorganisms commonly bacteria and fungi (Shin et al., 2006; Immanuel et al., 2006).

In this study fungi species were actually isolated from degrading corn cobs and tested for their cellulase activity by measuring the amount of reducing sugar produced by the fungi species.

\section{MATERIALS AND METHODS}

Collection of Samples: Corn cobs were collected from refuse dumps in a local market in Ajegunle area of Oyo town in Oyo state, Nigeria. Isolation and Identification of Isolates. Fungi species were isolated using potato dextrose Agar (PDA) and Yeast extract agar (YEA) using pour plate and spread plate techniques. Identification of fungal isolates were done by microscopic observation using methylene blue stain and compared to standard diagram of already identified fungi in fungi compendium.

\section{Growth of fungi and Production of Cellulase}

The fungal species were separately grown and tested for production of cellulase in submerged culture in a chemically defined media composed of $\mathrm{KH}_{2} \mathrm{PO}_{4}\left(1 \mathrm{gl}^{-1}\right)$, $\mathrm{MgSO}_{4} 7 \mathrm{H}_{2} \mathrm{O}\left(\mathrm{O} .5 \mathrm{gl}^{-1}\right)$, Yeast extract $\left(1 \mathrm{gl}^{-1}\right)$, Calcl2 $\mathrm{H}_{2} \mathrm{O}$ $\left(0.14 \mathrm{gl}^{-1}\right)$, thiamine $\left(0.0025 \mathrm{gl}^{-1}\right)$, glucose $(1 \%)$ (Vahidi et al., 2004). The cultures were grown at $32^{\circ} \mathrm{C}$ for 21 days. Culture broths were sampled at different days during growth to determine enzyme- production by Carboxyl methyl cellulose (CMC) hydrolysis.

\section{Effect of Carbon Source on Cellulase Production}

One percent (1\%) carboxyl methyl cellulose (CMC) was used to replace glucose as the carbon source in the chemically defined medium and the cultures were grown at $32^{\circ} \mathrm{C}$ for 21 days. Culture broths were sampled for enzyme production.

\section{Enzyme Assay}

Cellulase activity was assayed by the determination of reducing sugar released from carboxyl methyl cellulose (CMC) using the method of Reese and Mandels (1963). The assay medium was $0.55 \% \mathrm{CMC}$ in $0.55 \mathrm{M}$ acetate buffer $(\mathrm{pH} \mathrm{5.5)}$ and $9 \mathrm{ml}$ of this were incubated with $1 \mathrm{ml}$ of the fungus filterate for 1 hour at $32^{\circ} \mathrm{c}$. The filterate of the uninoculated control was also obtained and similarly assayed. The reducing sugar produced was assayed by dinitrosalicylic acid (DNSA) method using glucose as the sugar standard and a standard glucose graph was constructed. The amount of reducing sugar produced by one $\mathrm{ml}$ of fungus filterate was calculated from this graph. Cellulolytic activity of the filterate was then expressed in terms of the amount of total Reducing Sugar R.S. per ml.

\section{RESULT}

Eleven fungi species designated as $F A, F B, F C, F D, F E$, $F F, F G, F H, F J$, and $F K$ were isolated from the degrading corn cobs. Table 1 shows the morphological, growth characteristics and identification of the fungal isolates. The cellulase activity of the fungi when glucose was used as the carbon source is seen in figure 1 . Aspergillus niger has the highest reducing sugar production of $0.82 \mathrm{mg} / \mathrm{ml}$ followed by Aspergillus oryzae $(0.75 \mathrm{mg} / \mathrm{ml})$. The lowest value of $0.01 \mathrm{mg} / \mathrm{ml}$ was recorded for Rhizopus oryzae, Mucor racemosus and Geotrichum candidum. Figure 2 shows the cellulase activity of fungi when carboxyl methyl cellulose (CMC) was used as the carbon source. The highest reducing sugar value of $1.68 \mathrm{mg} / \mathrm{ml}$ was produced by Aspergillus niger while the lowest value of $0.69 \mathrm{mg} / \mathrm{ml}$ was produced by Mucor racemosus. 
Table 1: Morphological, growth characteristic and identification of fungal isolates

\begin{tabular}{|c|c|c|c|c|c|}
\hline Isolate & $\begin{array}{l}\text { Surface growth on } \\
\text { laboratory media }\end{array}$ & $\begin{array}{c}\text { Description of the characteristic feature } \\
\text { of fungi }\end{array}$ & $\begin{array}{l}\text { Growth } \\
\text { rate }\end{array}$ & $\begin{array}{l}\text { Reverse } \\
\text { coloured or } \\
\text { uncoloured }\end{array}$ & Identification \\
\hline FA & $\begin{array}{|lr|}\text { While to grayish } \\
\text { brown colonies about } \\
1 \mathrm{~cm} \text { with tendency to } \\
\text { collapser } \quad \text { Black }\end{array}$ & $\begin{array}{l}\text { Colonies are raised, about } 1-2 \mathrm{~cm} \text { high. } \\
\text { Stolon hyaline sporangiophore arising } \\
\text { directly from stolon or aerial lyphae. } \\
\text { Sporangia black }\end{array}$ & Fast & Cream & \begin{tabular}{|l|} 
Rhizopus \\
oryzae
\end{tabular} \\
\hline FB & Dirty green colonies & $\begin{array}{l}\text { Colonies are raised conidiophore with } \\
\text { large globose vesicle, metulae are nflated } \\
\text { and club shaped and are borne on the }\end{array}$ & Fast & Cream & $\begin{array}{l}\text { Aspergillus } f \\
\text { lav us }\end{array}$ \\
\hline FC & 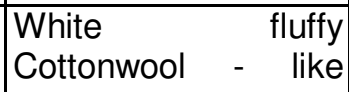 & $\begin{array}{l}\text { Colonies are raised. Intact conidia heads, } \\
\text { non septate iypae }\end{array}$ & Fast & Cream & $\begin{array}{l}\text { Mucor } \\
\text { racemosus }\end{array}$ \\
\hline FD & \begin{tabular}{|l}
$\begin{array}{l}\text { Chocolate } \\
\text { colonies }\end{array}$ \\
\end{tabular} & $\begin{array}{l}\text { Intact conidia heads conidiophore arising } \\
\text { from thick walled conidia conidiophore } \\
\text { hyaline to brown, mostly smooth walled } \\
\text { conidia at maturity globose irregularly } \\
\text { roughened with conspicuous ridges. }\end{array}$ & Fast & Brown & $\begin{array}{l}\text { Aspergillus } \\
\text { niger }\end{array}$ \\
\hline FE & $\begin{array}{l}\text { Grey } \\
\text { white colonies with } \\
\text { raised colonies }\end{array}$ & $\begin{array}{l}\text { Densely branched conidiophore straight } \\
\text { elevate to ellipsoids. Branches arising } \\
\text { fairly low in the conidiophore. Conidia } \\
\text { globose, conspicuously roughened }\end{array}$ & Slow & Cream & \begin{tabular}{|l|} 
Pencillium \\
atrovenetum
\end{tabular} \\
\hline
\end{tabular}

Table 1 Continues

\begin{tabular}{|c|c|c|c|c|c|}
\hline FF & $\begin{array}{ll}\text { Greyish } & \text { green } \\
\text { mycelium } & \end{array}$ & $\begin{array}{l}\text { Colonies fast growing, reaching } 5-5 \mathrm{~cm} \text { dia } \\
\text { after } 10 \text { days conidia sub globose or } \\
\text { ellipsoidal penicili two-three stage } \\
\text { branched with numerous usually } \\
\text { somewhat appraised metulae }\end{array}$ & Fast & Cream & $\begin{array}{l}\text { Pencillum } \\
\text { expansum }\end{array}$ \\
\hline FO & $\begin{array}{l}\text { Ligh brown powdery } \\
\text { mycelium } \quad \text { white } \\
\text { hyphae }\end{array}$ & $\begin{array}{l}\text { Colonies spreading broadly with abundant } \\
\text { aerial mycelium late became bluff from } \\
\text { production of rough walled sterile sepea. }\end{array}$ & Fast & Light brown & $\begin{array}{l}\text { Botryotrichum } \\
\text { pilulifemm }\end{array}$ \\
\hline $\mathrm{FH}$ & $\begin{array}{ll}\text { Bluish } & \text { green } \\
\text { mycelium } & \end{array}$ & $\begin{array}{l}\text { Large globose conidiophore are arising } \\
\text { from long broad thickened foot cell }\end{array}$ & Fast & & $\begin{array}{l}\text { Aspergillus } \\
\text { oryzae }\end{array}$ \\
\hline $\mathrm{FI}$ & White flufly Mycelium & $\begin{array}{l}\text { Fast growing white colonies white } \\
\text { butyrous and membraneous advancing } \\
\text { hyphae dichotomously branched conidia } \\
\text { chain mostly aerial and erect. }\end{array}$ & Fast & $\overline{\Lambda_{-}}$ & $\begin{array}{l}\text { Geotrichum } \\
\text { candidum }\end{array}$ \\
\hline FJ & $\begin{array}{l}\text { Bluish } \\
\text { mycelium }\end{array}$ & $\begin{array}{l}\text { Conidia globose to ellipsoidal smooth } \\
\text { walled colonies blue, grey or grey green, } \\
\text { velvety reverse, intensely yellow }\end{array}$ & Slow & Yellow & $\begin{array}{l}\text { Pencillium } \\
\text { chrysogenum }\end{array}$ \\
\hline FK & Grey colonies & $\begin{array}{l}\text { Brownish grey with much aerial mycelium } \\
\text { and rather few conidiophore, reverse } \\
\text { yellow conidiophore arising from creeping } \\
\text { aerial hyphae short, mostly } \\
\text { monoverticillate, few small phialides with } \\
\text { thin conidia bearing necks, conidia in short } \\
\text { chains globose and conspicuously } \\
\text { rouahened. }\end{array}$ & Slow & Yellow & $\begin{array}{l}\text { Penicilium } \\
\text { restrictum }\end{array}$ \\
\hline
\end{tabular}




\section{DISCUSSION}

Eleven fungal species were isolated from the degrading maize cobs which include Aspergillus flavus, Aspergillus niger Aspergillus oryzae, Rhizopus oryzae, Mucour racemosus, Botryctrichurn piluliferum and Geotichum candidurn; others are Penicillum expansum, Penicillium atrovenetum, Penicilium chrysogenum and Penicillum restrictum (Table 1). All the fungal isolates have their highest production of reducing sugar on day 7 when glucose was used as the carbon source (figure 1). While the highest production of reducing sugar when carboxyl methyl cellulose was the carbon source for growth was day 14. This shows that carbon source affect enzyme production. This was also observed by Milala et al. (2005) where the time course for enzyme production by Aspergillus niger differ depending on the substrate differs; guinea corn day 5 , maize day 3 , millet day 4 , and rice day 3 .

The longer day required by CMC based media may be due to the lower rate of growth by the organism in the media compared to that of glucose. Industrially useful enzymes either associated with the microbial cells or exoenzymes are often synthesized by microorganism during balanced growth (Prescott el al., 2008).

A high reducing sugar production of $1.68 \mathrm{mg} / \mathrm{ml}$ was obtained for Aspergillus niger when CMC was the carbon source compared with the value $0.82 \mathrm{mg} / \mathrm{ml}$ when glucose was the carbon source. Immanuel et al. (2007) also obtained a higher level of cellulase enzyme production from sawdust than coir ret. The amount of cellulase produced varied because of the influence of carbon source and growth of cellulolytic organism (Mandels and Reese, 1985). All species of Aspergillus and most of the Penicillium species has very high reducing sugar production; A niger (1.68 sugar); A flavus $(1.24 \mathrm{mg} / \mathrm{ml}) ; \quad A$ oryzae $(1.08 \mathrm{mg} / \mathrm{ml}) ; \quad P$ expansion $(1.60 \mathrm{mg} / \mathrm{ml}) ; P$ atrovenetum $(1.43 \mathrm{mg} / \mathrm{ml})$. Fungal of the genera Aspergillus and Penicillium are good cellulase producer (Immanuel, 2005; Milala et al., 2005; Hoffman and Wood, 1985).

Mucor racemocus had the lowest reducing sugar production, both $\mathrm{CMC}$ and glucose as carbon source $(0.6 \mathrm{mg} / \mathrm{ml} \& 0.01 \mathrm{mg} / \mathrm{ml}$ respectively). Several species of mucor which include Mucor pusillus and Mucor michei are not cellulolytic (Tausey, 1971).

Screening fungi associated with corn- cob degradation has shown that not all the fungi species are cellulolytic; however various species of Aspergillus and Pencillum will be useful in further degradation of corncob into more nutritive product for animal feed.

\section{CONCLUSION}

The cellulase activity of eleven fungal isolate has been studied. The genera Aspergillus and Penicilum are good cellulase producers but the level of production is based on the carbon source used in the medium. Fungi are good cellulase producers and will be useful in the conversion of cellulose in agricultural waste into simple sugar, which will make it easily digestible in animal feed.

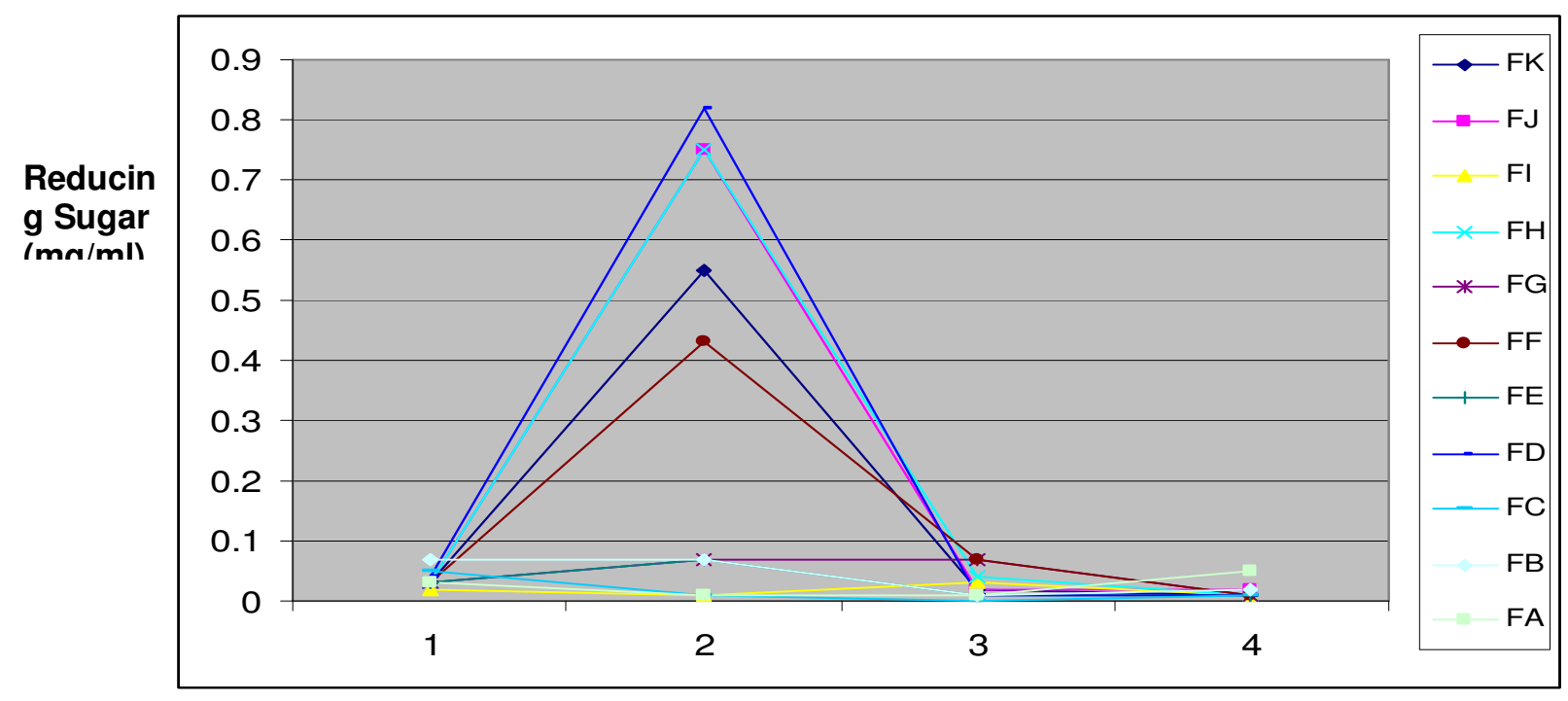

Days of Incubation

Figure 1: Cellulase activity of fungi at different days of incubation using glucose as carbon source 


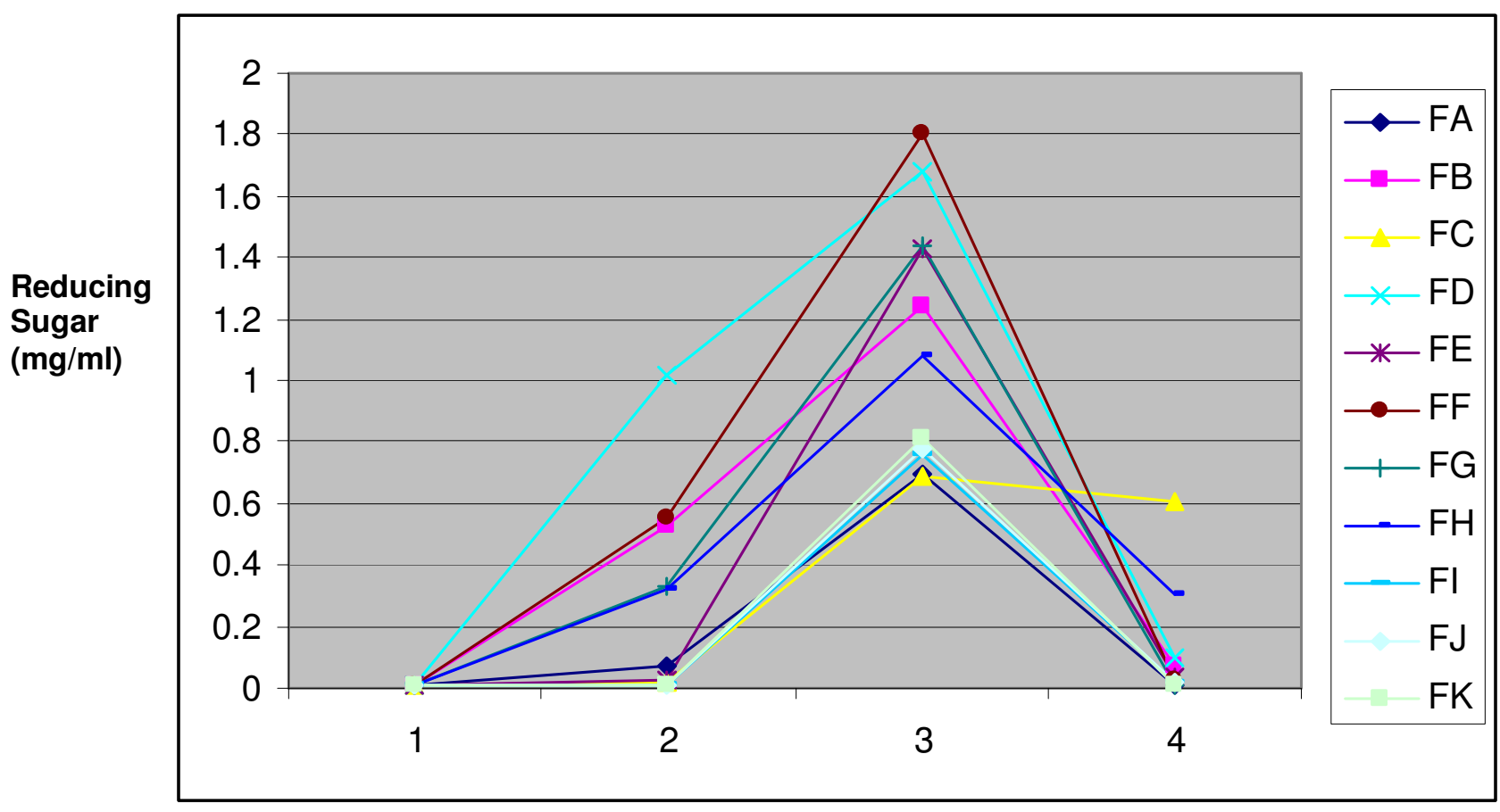

Days of Incubation

Figure 2: Cellulase activity of fungi at different days of incubation with $\mathrm{CMC}$ as carbon source

\section{REFERENCES}

Hoffman RM and Mod TM (1985). Isolation and Partial Characterization of a Mutant Penicillium for the Saccharification of Straus Biotechnol. Bioeng. 27:8185.

Immanuel GA, Akila Bhagavath CM, lyappa Raj O, Esakkraj P and Palavesam A (2007). Production and Partial Purification of Cellulase by Aspergillus niger and A fumigatus fermented in Coir waste and Sawdust. The Internet Journal of Microbiology. 3(1): 1-17.

Milala MA, Shugaba A, Gidado A, Ene AC and Wafar JA (2005). Studies on the use of Agricultural wastes for cellulase enzyme production by Aspergillus niger.

Oso BA (1978). The Production of Cellulase by Talaromyces Emersonii. Mycologia vol LXX (3): 577585.

Prescott ML, Harley JP and Klein DA (2008). Microbiology Sixth Ed. McGraw Hill Pub.

Reese ET and Mandels (1963). Enzymic Hydrolysis of Cellulose and its Derivatives in Methods in carbohydrate Chemistry VVhistler R.I. Ed. Academic
Press New York Vol. II; 139-143.

Shin CS, Hee HP, Lee IS and Park SC (2000). Enzyme Production of Trichoderma ressei rutc -- 30 on various lignocellulolytic substrates. App. Biochem. Biotech. 84 - 86 (1-9): 237-245.

Tausey MR (1971). Agar Diffusion Assay of Cellulolytic Ability of Thermophilic Fungi. Archmicrobiol. 77:1-11.

Tuah AK and Oskor ER (2008). Degradation of Untreated and Treated Maize Cobs and Cocoa Pod Husks in the Rumen in FAO Corporated Document Renousilory. http//.wwwfao.wanlos 11.R 1x5490.

Vahidi O, Pafard F and Narjoyan F (2004). Effect of Cultivation Conditions on Growth and Antifungal Activity of Mycerja deptocephala. Afr. J. Biotech. 3 (2): 606-609.

Zhin YS, Ggo H, Fei JX and Sum CN (1988). Induction and Regulation of Cellulase Synthesis in Trichoderma Mutant EA 3 - 867 and N2 -- 78. Enzyme of Micobial Technol. 4:3-12.

NOTE: The following authors were cited in the content but not listed as reference:

Immanuel et al. (2006); Immanuel, 2005; Milala, 2005 